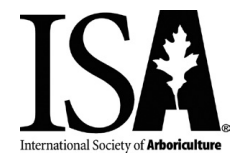

Arboriculture \& Urban Forestry 2016. 42(4): 253-266

\title{
Large Oriental Bittersweet Vines Can Be Killed by Cutting Alone: Implications for Utility Arboriculture and Other Hazard Tree Work
}

\author{
Christopher A. Nowak and Caryl J. Peck
}

\begin{abstract}
Oriental bittersweet (Celastrus orbiculatus) is an invasive, exotic, woody vine introduced to North America in the mid- to late 1800s from East Asia. This vine is problematic because it can kill trees through competition and mechanical stress, which in turn creates problems for tree care professionals in utility right-of-way and other hazard tree work. Oriental bittersweet is becoming more prevalent as a problem throughout the eastern United States. Two manipulative field experiments were conducted across the Hudson Valley in New York State to test the timing of cutting and glyphosate herbicide effects on large vine mortality. While results from the first year indicated that herbicides were needed with vine cutting to achieve high mortality rates, this was not true with second year results. Cutting vines without herbicides produce the same, high rate of mortality of oriental bittersweet vines after the second year $(>90 \%$ kill) as cut-stump treatments with herbicides. It may be important that high kill of cut vines is related to large vine size, and that stumps were in forest shade. Herbicides may not be necessary to kill cut-stump methods to kill oriental bittersweet vines that have a minimum stem diameter $>2-3 \mathrm{~cm}$ and are growing in areas where stumps are in shade.

Key Words: Accord ${ }^{\circledR}$; Celastrus orbiculatus; Cut Surface; Danger Tree; Efficacy; Hazard Tree; Hudson Valley; Liana; New York; Oriental Bittersweet; Vegetation Management.
\end{abstract}

Oriental bittersweet (Celastrus orbiculatus) is an invasive, exotic vine, historically prized for the ornamental value of its bright red berries and for its usefulness in landscaping and controlling roadside erosion (Patterson 1974; Dreyer et al. 1987). The vine was introduced to North America in the mid- to late-1800s from East Asia, where it is native to Japan, Korea, and China north of the Yangtze River (Hou 1955). The woody vine (a liana) was first observed in New York City in 1897 (Steward et al. 2003). Naturalized populations were first recognized sometime between 1910 and 1920, and it was found in 21 of the United States by 1970 (Patterson 1974). Today, in New York State, oriental bittersweet is present across the state but is found in problematic high densities and advanced growth and development in the Hudson and Mohawk Valleys (C. Nowak and C. Peck, personal observation). This is likely due to radial spread along roadside edges from introduction centers and encouraged by valley climates.
Woody vines in general have long been recognized as a potential threat to the normal or desired development of trees and forest stands (Lutz 1943; Siccama et al. 1976; Trimble and Tyron 1979; McNab and Meeker 1987; Schnitzer and Bongers 2002). Specific problems with vines include changes in forest ecosystem regeneration and successional processes, competition for sunlight, and mechanical damage to individual trees. Oriental bittersweet can cause all of these problems. Unlike native Virginia creeper (Parthenocissus quinquefolia), poison ivy (Toxicodendron radicans), and wild grapevine (Vitis spp.), common vines in the eastern United States that attach to trees and other supports using tendrils and rootlets, twiners like oriental bittersweet constrictively wrap vine sections around tree stems up through to the top of the canopy. These twined vines can girdle stems and increase weight load of the crown canopy. Both effects, together or separately, can cause trees to become hazardous due to increased risk of 
breakage and total collapse. Trees that have eminent risk of collapse (i.e., hazard trees) require arborists, foresters, and other tree care managers to remove them before they degrade, become more hazardous, and cause property damage or personal injury.

Hazard trees have received heightened attention in the electric utility industry, especially with elevated efforts to maintain safe and reliable transmission of electricity (Nowak 2010). Electric transmission line rights-of-way (ROWs) commonly pass through forested areas across North America. In New York and the New England area, for example, forests adjoin $60 \%-80 \%$ of powerline corridor edges (Guggenmoos and Sullivan 2007). In the state of Connecticut, off-ROW land uses along $115 \mathrm{kV}$ transmission lines were most commonly forest $(50 \%)$ or residential (38\%) (Puolos and Camp 2010). A large portion of the off-ROW forest land has maturing tree communities that present a high and persistent potential for trees to fall into the ROW. The total number of possible danger trees-trees on or off the right-of-way that could contact electric supply lines if they fall (ANSI 2012)-in the northeastern U.S. has been estimated to be well over $4,000,000$ trees (Nowak 2010). A small, but important subset of these danger trees are also hazard trees (i.e., trees that are structurally unsound). Little research has been conducted on off-ROW danger and hazard trees for electric transmission lines, and all of that research has been recent (Guggenmoos and Sullivan 2007; Nowak 2010; Puolos and Camp 2010). Problems with trees and electric outages in electric distribution has slightly longer standing interest and research (Simpson and Van Bossuyt 1996; Guggenmoos 2003). Understanding and management of danger and hazard trees has also been of recent interest in other professions and disciplines, including recreation management, arboriculture and urban forestry, and wildlife management (see: Manning et al. 2002; USDA FS 2006; Maruthaveeran and Yaman 2010). Accredited sets of standards and guidelines for managing off-ROW risk trees have been recently developed (UAA 2009; ANSI 2011; ANSI 2012) for the electric utility industry. Guidance on the identification, evaluation, and assessment of off-ROW danger and hazard trees have been developed using tree morphology and other techniques to reduce risk and costs associated with selective cutting and removal of high-risk trees. Identification of hazard trees is based primarily on judging the condition of the tree and its potential for failure. Tree failure can occur with both sound and defective trees, but defective trees are considered more susceptible to failure because of structural weaknesses in stems and roots (Albers et al. 2006). A structurally sound danger tree (low hazard) can fall into a conductor because of high winds. The same tree with defects or other problems (e.g., vines) will have a greater chance of failing in high winds and therefore presents both higher hazard and risk. It is the higher risk trees that may warrant vegetation management treatment.

Oriental bittersweet and other vines (e.g., grape, Virginia creeper, poison ivy) can elevate hazard by increasing the chance of tree failure due to increase potential for crown breakage by way of accelerated branch death and increased weight of the crown, which may cause sections of crown breakage or whole trees to fail. Additionally, oriental bittersweet can constrict main stems as it twines and wraps up a tree, causing structural defects along the tree bole. Controlling oriental bittersweet before it can cause trees to become hazardous has become an important part of tree management in natural and human-built environments (Dreyer 1994; Williams and Timmins 2003), but published research specific to cut-stump herbicide effects on oriental bittersweet are lacking. Two publications on the use of mechanical and chemical control of oriental bittersweet vines were short duration studies as nonrefereed Master of Science theses (Lynch 2009; Wooten 2013). Recommendations for using herbicides and cut-stump methods to control oriental bittersweet are common in the form of information sheets and weed control handbooks (e.g., Dreyer 1994; Williams and Timmins 2003), wherein it is postulated that herbicide treatments are needed to control root suckering and stump sprouting after cutting. A notion of sprouting and suckering in bittersweet is not surprising given how many other woody plants readily sprout from adventitious buds as a form of vegetative reproduction. The use of herbicide in conjunction with cutting is well understood as a way to control stump sprouts and root suckers of trees (Abrahamson 1983; Zedaker et al. 1987; Ballard and Nowak 2006; Kochenderfer et al. 2006; Petrice and Haack 2011), but not necessarily with woody vines. In general, various herbicides, and especially those with glyphosate as the active ingredient, can be 
used to readily kill woody plants, particularly with later season treatments (Ballard and Nowak 2006).

Two replicated field experiments were established in New York State's Hudson Valley to determine the effects of cutting and cut surface herbicide treatments with glyphosate on mortality of large oriental bittersweet vines. Based on work with trees (e.g., see Ballard and Nowak 2006), it was hypothesized that Accord ${ }^{\oplus}$ herbicide [active ingredient (a.i.): glyphosate] (Dow AgroSciences, Indianapolis, Indiana, U.S.) applied to freshly cut bittersweet stumps would result in significant mortality of treated vines, and that percent kill would be greatest with the highest concentration of glyphosate applied late in the season, as compared to no herbicide or low concentrations applied earlier in the growing season. A randomized block factorial experiment at one site and a randomized block experiment across three sites were established during the 2011 growing season and treatment effects measured in summer 2012 and autumn 2013, effectively one and two growing seasons after treatment. Patterns of mortality and sprouting in the first year following treatment supported the hypothesis that glyphosate herbicide can increase the amount of kill and reduce sprout numbers and growth, but surprisingly, early-summer treatments with herbicides were more efficacious than autumn treatments. At the end of the second growing season after treatment, differential treatment effects disappeared-vine mortality was high across all treatments, leading to a conclusion that herbicides may not be needed to achieve a high degree of control of large, cut, oriental bittersweet vines.

\section{METHODS AND MATERIALS}

\section{Study Areas}

Study plots were laid out along field/forest edges on the National Park Service's Vanderbilt National Historic Site in Hyde Park (Study 1, and one block

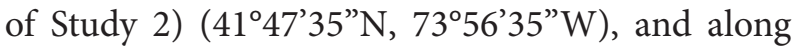
roadside ROWs near the village of Lake George $\left(43^{\circ} 25^{\prime} 45^{\prime \prime} \mathrm{N}, 73^{\circ} 43^{\prime} 15^{\prime \prime} \mathrm{W}\right)$, and just outside New York City near the towns of Stony Point $\left(41^{\circ} 16^{\prime} 55^{\prime \prime} \mathrm{N}\right.$, $73^{\circ} 57^{\prime} 41^{\prime \prime} \mathrm{W}$ for one treatment plot) and East Fishkill $\left(41^{\circ} 34^{\prime} 23^{\prime \prime} \mathrm{N}, 73^{\circ} 46^{\prime} 48^{\prime \prime} \mathrm{W}\right.$ for two treatment plots). Field/forest edges were studied because it is known that bittersweet is commonly abundant along these forest edge sites (Robertson et al. 1994;
Merriam 2003; Londré and Schnitzer 2006). Electric transmission line ROWs produce extensive lengths of forest edge, which is why oriental bittersweet is an important problem for utility foresters, as well as other arborists and vegetation managers.

The study areas were located entirely within the Hudson Valley Section of the Eastern Broadleaf Forest Province and Hot Continental Division (Section 221B) (McNabb and Avers 1994). Across the Hudson Valley, average annual precipitation is $102 \mathrm{~cm}$, average annual temperature ranges from $7^{\circ} \mathrm{C}$ to $10^{\circ} \mathrm{C}$, and the growing season lasts from 160 to 180 days (McNab and Avers 1994). These environmental conditions are conducive to the spread, growth, and persistence of oriental bittersweet (Dukes et al. 2009). The northern site (Lake George) is apparently near the current northern distribution of oriental bittersweet in New York State, and the southern sites (East Fishkill and Stony Point) are near to where oriental bittersweet may have entered into New York (just north of New York City).

Soils associated with the study sites included Dystrochrepts and Fragiachrepts with udic moisture and mesic temperature regimes in the southern and middle areas of the section, and Hapludalfs with udic moisture and mesic temperature regimes in the north. Soil series were all excessively well-drained and apparently included (Natural Resources Conservation Service 2014): Hinckley soils in the Lake George block, a Nassau-Cardigan complex of soils in the Hyde Park blocks, an unidentified Udortent associated with a pit-quarry operation on one south block plot (Stony Point), and Hoosic soils in the other two south plots (East Fishkill). Soils in the Lake George and the Stony Brook plots appeared to be anthropic, as the landforms had apparently been reworked with heavy machinery during highway construction and maintenance.

Experimental blocks associated with both studies were fully-stocked forests that ranged in age from 40 to 80 years (C. Nowak, personal observation). The forest types were as expected for the Hudson Valley-various combinations of northern hardwoods and Appalachian oaks. The most important tree species across the study areas were sugar maple (Acer saccharum), tree-ofheaven (Ailanthus altissima), black locust (Robinia pseudoacacia), and red oak (Quercus rubra) for the Hyde Park site, and flowering dogwood 
(Cornus florida), green ash (Fraxinus pennsylvanica), black cherry (Prunus serotina), and red oak for the East Fishkill and Stony Point plots (Peck 2014). The Lake George site was occupied by 40 -year-old white pine (Pinus strobus).

\section{Experimental Design and Vine Treatments}

Study plots, which are also the "experimental units," were established in 2011 along forest edges that contained at least 10 large $(>1.3 \mathrm{~cm}$ diameter), twining (climbing to near the top of trees) vines per $100 \mathrm{~m}^{2}$ area. All plots extended $10 \mathrm{~m}$ into the forests and were $10 \mathrm{~m}$ wide for Study 1, and $30 \mathrm{~m}$ wide for Study 2 . At least $3 \mathrm{~m}$ of untreated buffer distance separated all plots, and commonly this distance was greater. Experimental design for Study 1 was a randomized complete block $3 \times 3$ factorial on one site (Hyde Park) with herbicide concentration as one factor, and month of treatment application the second factor; for Study 2, it was a randomized complete block design to test herbicide concentration on three sites (blocks) across the Hudson Valley.

Treatments were based on cutting vines within 15 to $45 \mathrm{~cm}$ of groundline (depending on vine form and access due to neighboring vines and other plants) with a hand saw to produce a horizontal surface so as to maximize retention of herbicide on the cut surface. Ten randomly selected and tagged (numbered) large vines within each treatment plot were cut within each plot (numbering allowed researchers to find the treated vines over time). A total of 360 vines were treated across the two studies. One-third of the vines were cut but did not receive an herbicide treatment (cut-only treatment). The remainder of the cut vines had herbicide treatments applied to the freshly cut vines to cover the cut surface of the stump using a syringe applicator $[60 \mathrm{cc} / \mathrm{ml}$ Terumo syringe without needle (Terumo Medical Corporation, Somerset, New Jersey, U.S.), attached to a $15 \mathrm{~cm}$ length of Primary IV line with a spin-lock connector (B. Braun Medical Inc., Bethlehem, Pennsylvania, U.S.)]. The syringe applicator was used to provide the precise application rates required for the study $(20 \mathrm{ml}$ herbicide mix per vine). However, cut-stump herbicide applications may also be made with backpack sprayers, pump bottles, or small spray bottles. It is expected that efficacy results as reported herein would not change with application equipment.

Herbicide concentrations were: 1) undiluted Accord (53.8\% glyphosate a.i.) (100\% unmixed solution); and 2) diluted Accord (26.9\% glyphosate a.i.) (50\% solution mixed with water). Treatments were applied in late-June, mid-August, and mid-October 2011 (only the October treatment date was used for Study 2).

Weather was within labeled strictures for use: the late-June treatment day was partly cloudy with temperature $\sim 27^{\circ} \mathrm{C}$, and the ground was wet from recent rain; mid-August treatment weather was $\sim 20^{\circ} \mathrm{C}$ and humid from a morning rain; late-October treatments occurred with the temperature between $4^{\circ} \mathrm{C}-7^{\circ} \mathrm{C}$, with snow occurring on some sites just after treatment.

\section{Population Characteristics of Untreated and Treated Vines}

All bittersweet vines $\geq 1.27 \mathrm{~cm}$ in diameter within each plot were measured for lower stem (within $30.5 \mathrm{~cm}$ of ground level) diameter with digital calipers. Understory oriental bittersweet (seedlings up to vines $1.27 \mathrm{~cm}$ diameter) were measured in paired understory quadrats in each plot (one pair in Study 1 plots, and three pairs in Study 2 plots). Quadrats in a plot were located $3 \mathrm{~m}$ (edge of field) and $6 \mathrm{~m}$ (interior in forest) from field edge into the forest along plot center (equidistant from plot edges for Study 2).

A $2-3 \mathrm{~cm}$ thick stem disc section was taken from each treated vine to determine vine size and age. Each disc was air dried, labeled with indelible marker, and catalogued. Discs were surfaced using an electric belt sander fitted with 150-grit paper and then polished using 400-grit sandpaper. Discs were examined using a $10 \times$ dissecting microscope (Wolfe model no. 864158, Carolina Biological Supply Company, Burlington, North Carolina, U.S.). Annual rings were counted in four directions at 90 degrees to each other in order to obtain an average number of rings. The process was repeated three times on each disc, and the average was used to estimate vine age.

\section{Measurement of Treatment Effects}

Each of the ten treated vines in each plot was examined one year (June 2012) and two years (October 2013) after treatment. Mortality of treat- 
ed vines was determined by a complete absence of sprouts and lack of green coloration below the bark layer (determined by scraping the bark slightly on the stump using a pocket knife). On surviving vines, the number of sprouts and sprout length were recorded for each treated stem in 2012. It was possible that the stumps of vines were killed with treatment, but not the roots. Root suckering was evaluated by searching for suckers in a $2 \mathrm{~m}$ zone around each treated vine, but no suckers were observed, indicating that if the vine stump was killed, so were the roots. Only mortality was measured at the end of the second year post treatment. Of the 360 vines treated in 2011, a subset of 326 were found in 2013 because vine ID tags were lost (likely destroyed by animals). A minimum of seven vines were found in each plot in 2013, allowing for meaningful calculations of second year mortality levels.

\section{Data Analyses}

A paired t-test was used to compare oriental bittersweet density between field edge and interior forest quadrats. Correlation analysis was used to test the relationship between average, plot-level vine size and age. Analysis of variance using general linear models was used to test the hypothesis that efficacy as determined by percent mortality (and sprout length and number in Year 1) would vary as a function of herbicide concentration (including the untreated control-cuts with no herbicide treatment) and treatment timing for Study 1, and herbicide concentration for Study 2. While it was possible to combine each year's mortality data and run a single analysis of variance using a repeated measures design to test for year (Year 1 versus Year 2) and treatment effects, separate analyses of variance were run for each year in each study, with the year effect deemed obvious based on study results-Year 1 results were clearly different from Year 2. Also, since practitioners would most likely judge treatment efficacy after treatment effects were fully expressed, and not using the average efficacy response (which is what the main effects in a single repeated measures analysis would produce), the two separate analyses of variance made practical sense.

An arcsine transformation of percent mortality, which is typical for analyzing survival data to better meet basic assumptions of analysis of variance (see Ahrens et al. 1990 and associated literature review), was applied to the data, but evaluation of treatment effects based on the transformed data did not change compared to the untransformed data. Therefore, all reported data analyses are untransformed.

Treatment means were separated using Duncan's method when $P$-values were $\leq 0.10$, though $P$-values up to 0.15 were considered as possibly significant. Interaction effects were judged as statistically significant using an alpha level of 0.15 (Stehman and Meredith 1995). All statistical analyses and calculations were performed with SAS $^{\circledast}$ version 9.3 (SAS Institute Inc. 2011).

\section{RESULTS}

\section{Oriental Bittersweet Populations}

Average number of small oriental bittersweet vines $(<1.3 \mathrm{~cm}$ in diameter) across Study 1 plots was 26,334 per ha, ranging from 0 to 118,037 per ha; for Study 2, the average was 19,660 vines per ha, ranging from 0 to 42,518 per ha. Field edge quadrats averaged nearly two times higher small vine density as compared to forest interior quadrats, 32,143 versus 17,904 vines per ha, respectively $(P<0.001$; paired t-test, $\mathrm{n}=54$ pairs).

Average number of large vines $(\geq 1.3 \mathrm{~cm}$ in diameter) across Study 1 plots was 2,222 per ha, ranging from 988 to 4,745 per ha; for Study 2, the average was 2,330 per ha, ranging from 946 to 4,273 per ha. These large vines were observed to be located across the plot, with only slight affinity for the field edge half (C. Nowak, personal observation). It is likely that when the large vines became established, the whole plot was more open and edge-like than it is today.

Average diameter of vines $\geq 1.3 \mathrm{~cm}$ across Study 1 plots was $2.8 \mathrm{~cm}$, ranging from 1.5 to $6.0 \mathrm{~cm}$; for Study 2, the average was $2.5 \mathrm{~cm}$, ranging from 1.8 to $4.1 \mathrm{~cm}$. Age of the oriental bittersweet for Study 1 averaged 18 years, ranging from 9 to 38 years, and for Study 2 the average age was 22 years, ranging from 10 to 36 years. The largest and oldest vine observed in the study had a stem diameter of $15.3 \mathrm{~cm}$ and was 48 years old. Large vine age and stem diameter were strongly, linearly correlated across the study sites (Studies 1 and 2 combined) $(\mathrm{r}=0.77 ; P=<0.0001 ; \mathrm{n}=36)$ (Figure 1$)$. 


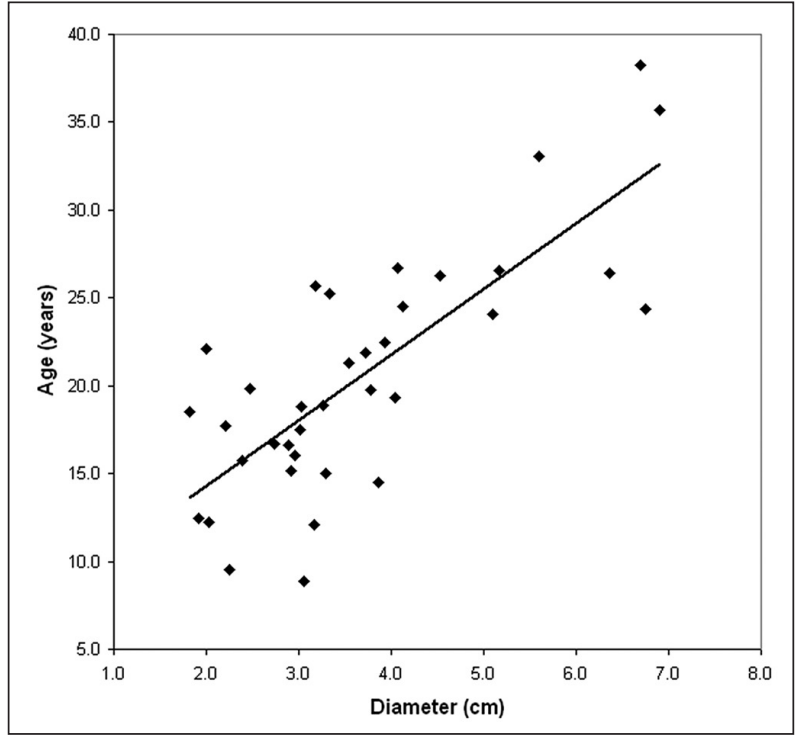

Figure 1. Relationship between average oriental bittersweet vine age and stem diameter (Studies 1 and 2 combined) ( $r$ $=0.77 ; P<0.0001$ ). Each observation is the average of 10 vines for each of the 36 treatment plots.

\section{Oriental Bittersweet Vine Responses to Cutting and Herbicide Treatments First Year After Treatment (Study 1)}

Percent mortality, number of sprouts and length of sprouts on surviving vines were affected by treatments. Early-season treatments were more efficacious than later treatments; lower herbicide concentration was as efficacious as high concentration. There was no interaction of treatment effects (Table 1).

Percent mortality ranged from $10 \%$ to $100 \%$, and averaged $73 \%$ across all treatments. June treatments $(87 \%)$ were more efficacious than August or October treatments (average: 66\%). Herbicide in high (91\%) or low $(82 \%)$ concentration was better than cutting only (44\%) in killing large oriental bittersweet, but there was no significant difference between low- and high-concentrations in effect (Table 1).

The average number of sprouts across all treatments was 2.0 per vine. Cutting only resulted in more sprouts (3.1 per vine) than herbicide treat-

Table 1. First and second year average oriental bittersweet vine responses to cut-stump treatments and associated analyses of variance results from Study 1 .

\begin{tabular}{|c|c|c|c|c|c|}
\hline \multirow{3}{*}{$\begin{array}{l}\text { Treatment Factors } \\
\text { Cut-stump treatment type }\end{array}$} & \multicolumn{3}{|c|}{ First year after treatment ${ }^{z}$} & \multicolumn{2}{|c|}{ Second year after treatment ${ }^{\mathrm{z}}$} \\
\hline & Percent mortality & $\begin{array}{l}\text { Number of sprouts } \\
\text { per vine }\end{array}$ & $\begin{array}{l}\text { Length of sprouts } \\
(\mathrm{cm})\end{array}$ & \multicolumn{2}{|c|}{ Percent mortality } \\
\hline & & & & & \\
\hline Cut only & $\begin{array}{l}44 \mathrm{~b} \\
(11)^{\mathrm{y}}\end{array}$ & $\begin{array}{l}3.1 \mathrm{a} \\
(0.9)\end{array}$ & $\begin{array}{l}55 \mathrm{a} \\
(4)\end{array}$ & \multicolumn{2}{|l|}{$\begin{array}{l}92 \mathrm{~b} \\
(4)\end{array}$} \\
\hline Herbicide: low concentration & $\begin{array}{l}82 \mathrm{a} \\
(9)\end{array}$ & $\begin{array}{l}2.1 \mathrm{ab} \\
(0.8)\end{array}$ & $\begin{array}{l}25 \mathrm{~b} \\
(10)\end{array}$ & \multicolumn{2}{|l|}{$\begin{array}{l}99 \mathrm{a} \\
(1)\end{array}$} \\
\hline Herbicide: high concentration & $\begin{array}{l}91 \mathrm{a} \\
(4)\end{array}$ & $\begin{array}{l}0.8 \mathrm{~b} \\
(0.4)\end{array}$ & $\begin{array}{l}28 \mathrm{~b} \\
(10)\end{array}$ & \multicolumn{2}{|l|}{$\begin{array}{l}100 \mathrm{a} \\
(0)\end{array}$} \\
\hline \multicolumn{6}{|l|}{ Time of treatment } \\
\hline June & $\begin{array}{l}87 \mathrm{a} \\
(9)^{\mathrm{y}}\end{array}$ & $\begin{array}{l}0.4 \mathrm{~b} \\
(0.2)\end{array}$ & $\begin{array}{l}47 \mathrm{a} \\
(13)\end{array}$ & \multicolumn{2}{|l|}{$\begin{array}{l}99 \mathrm{a} \\
(1)\end{array}$} \\
\hline August & $\begin{array}{l}69 \mathrm{~b} \\
(11)\end{array}$ & $\begin{array}{l}2.5 \mathrm{a} \\
(0.9)\end{array}$ & $\begin{array}{l}40 \mathrm{a} \\
(10)\end{array}$ & \multicolumn{2}{|l|}{$\begin{array}{l}95 \mathrm{a} \\
(4)\end{array}$} \\
\hline October & $\begin{array}{l}62 \mathrm{~b} \\
(12)\end{array}$ & $\begin{array}{l}3.0 \mathrm{a} \\
(1.0)\end{array}$ & $\begin{array}{l}31 \mathrm{a} \\
(9)\end{array}$ & \multicolumn{2}{|l|}{$\begin{array}{l}98 \mathrm{a} \\
(2)\end{array}$} \\
\hline Analysis of variance sources of $v$ & $\begin{array}{l}\text { ion and associated } P \\
\text { Degrees of } \\
\text { freedom }\end{array}$ & \multicolumn{2}{|l|}{$P$-values } & & \\
\hline Block & 2 & 0.06 & 0.95 & 0.04 & 0.08 \\
\hline Stump treatment (ST) & 2 & $<0.01$ & 0.11 & 0.02 & 0.08 \\
\hline Treatment time (TT) & 2 & 0.07 & 0.04 & 0.13 & 0.44 \\
\hline $\mathrm{ST} \bullet \mathrm{TT}$ & 4 & 0.27 & 0.25 & 0.43 & 0.19 \\
\hline Error & 16 & & & & \\
\hline
\end{tabular}


ment (average of 1.4 per vine). Early treatment resulted in lower numbers of sprouts ( 0.4 per vine) than mid- or late-season treatments, which had 2.5 and 3.0 sprouts per vine, respectively (Table 1 ).

Length of sprouts in cut-only treatments (average: $55 \mathrm{~cm}$ ) was greater than in herbicide treatments (combined average $26 \mathrm{~cm}$ ). Sprouts as long as $127 \mathrm{~cm}$ were recorded in cut-only treatments and averaged $38 \mathrm{~cm}$ in length across all treatments. There was no significant difference in average sprout length based on time of treatment (Table 1).

\section{First Year After Treatment (Study 2)}

Percent mortality was marginally affected by treatments; number of sprouts and length of sprouts on surviving vines was not (Table 2). Low- and high-concentration herbicide treatments produced the same percent kill (67\%) that was statistically, significantly greater than that observed with cutting alone (13\%). Percent kill with herbicides was similar to that observed in Study 1 (October only $=62 \%$ ), but percent mortality with cut-only was lower, with $13 \%$ for Study 2 compared to an overall 44\% for Study 1 .

The average number of sprouts and length of sprouts across all treatments was 2.0 per vine and $55 \mathrm{~cm}$ per sprout (Table 2 ). Unlike Study 1, there was no change in characteristics of sprouting with treatment.

\section{Second Year After Treatment (Study 1)}

Percent mortality was still affected by treatments in the second year, with cut-only at $92 \%$ and the herbicide treatments averaging nearly 100\% (Table 1). Mortality was the same across the different treatment times, June through October. There was no interaction of treatment effects (Table 1).

\section{Second Year After Treatment (Study 2)}

Percent mortality was not affected by treatments (Table 2). Average percent mortality across treatments was $89 \%$, ranging from $70 \%$ to $100 \%$.

\section{DISCUSSION}

Abundances of both small and large oriental bittersweet vines were high across the study sites. Sites were chosen to have a high number of vines for consistent high opportunities for treatment, focusing on those vines with diameters that were 2 to $3 \mathrm{~cm}$ in size at a minimum. While 10 vines were treated per plot, which equates to nearly 1,000 vines per ha in Study 1 and just over 300 per ha in Study 2, there were still thousands of other, untreated vines along the field and roadside ROW edges. Additionally, there were thousands of vines per ha that were less than $1 \mathrm{~cm}$ diameter. While these small vines were not part of the efficacy study (only those vines with a $1.3 \mathrm{~cm}$ diameter or greater), they indicate the magnitude

Table 2. First and second year average oriental bittersweet vine responses to cut-stump treatments and associated analyses of variance results from Study 2.

\begin{tabular}{|c|c|c|c|c|c|}
\hline & \multicolumn{3}{|c|}{ First year after treatment ${ }^{z}$} & \multicolumn{2}{|c|}{ Second year after treatment ${ }^{z}$} \\
\hline & Percent mortality & $\begin{array}{l}\text { Number of sprouts } \\
\text { per vine }\end{array}$ & $\begin{array}{l}\text { Length of sprouts } \\
(\mathrm{cm})\end{array}$ & Percen & \\
\hline \multicolumn{6}{|l|}{ Cut-stump treatment type } \\
\hline Cut only & $\begin{array}{l}13 \mathrm{~b} \\
(3)^{\mathrm{y}}\end{array}$ & $\begin{array}{l}2.8 \mathrm{a} \\
(0.5)\end{array}$ & $\begin{array}{l}62 \mathrm{a} \\
(22)\end{array}$ & $\begin{array}{l}70 \mathrm{a} \\
(25)\end{array}$ & \\
\hline Herbicide: low concentration & $\begin{array}{l}67 \mathrm{a} \\
(28)\end{array}$ & $\begin{array}{l}0.7 \mathrm{a} \\
(0.3)\end{array}$ & $\begin{array}{l}10 \mathrm{a} \\
(8)\end{array}$ & $\begin{array}{l}97 \mathrm{a} \\
(3)\end{array}$ & \\
\hline Herbicide: high concentration & $\begin{array}{l}67 \mathrm{a} \\
(19)\end{array}$ & $\begin{array}{l}8.1 \mathrm{a} \\
(6.8)\end{array}$ & $\begin{array}{l}36 \mathrm{a} \\
(16)\end{array}$ & $\begin{array}{l}100 \mathrm{a} \\
(0)\end{array}$ & \\
\hline Analysis of variance sources of $v$ & $\begin{array}{l}\text { ation and associated } \\
\text { Degrees } \\
\text { of freedom }\end{array}$ & $\begin{array}{l}\text { lues } \\
P \text {-values }\end{array}$ & & & \\
\hline Block & 2 & 0.21 & 0.44 & 0.10 & 0.33 \\
\hline Stump treatment & 2 & 0.13 & 0.47 & 0.22 & 0.33 \\
\hline Error & 4 & & & & \\
\hline
\end{tabular}

${ }^{\mathrm{z}}$ Means followed by the same letter within Cut-stump treatment type are not statistically different from each other (Duncan's, alpha $\left.=0.10\right)$.

y Standard errors are in parentheses.

Note: Sample size for treatment means was three for all variables. 
of the oriental bittersweet problem and provide context for management. Specifically, even if researchers controlled all the large vines per site, there would still be thousands more small vines to recolonize the released trees. Yet, once a vine is controlled on a tree, it should take many years before a new vine (seedling or sprout) develops fully into a renewed problem on that tree. Since all of the trees with treated vines were still alive, and the range of average ages for the studied vines was between 9 and 38 years, one can expect it will take decades after initial vine control before new vines produce the same problem for the same trees. Putz (1991) made a similar observation in his long-standing studies of liana vines around the world. He stated that while most cut liana stumps sprout, the sprouts generally grow slowly and fail to grow back up into the mature forest canopy.

In the first year after treatment, herbicide treatments did reduce sprouting and resulted in higher mortality of treated oriental bittersweet vines compared to vines that were cut-only. In both Studies 1 and 2, the lower concentration herbicide treatment (26.9\% a.i. glyphosate) produced levels of mortality that were effectively the same as the high-concentration herbicide treatment. Average mortality for low- and high-concentration herbicide treatments in Study 1 was $82 \%$ and $91 \%$, respectively, while for Study 2, they were 67\% and $67 \%$, respectively. The lower percent mortality in Study 2 may be due to there only being an October treatment. In Study 1, the October treatment had a lower percent mortality than June, yet the same for August-the overall average mortality of Study 1 includes the high percent mortality for June.

It is not clear why the June treatment produced a higher mortality rate than August or October in Study 1; this is opposite to what was expected in the study, based on previous work with cutstump treatment of trees (Ballard and Nowak 2006; Note that the Ballard and Nowak study did not include cutting alone). It may be that cut vines in June have a lowered stored carbon in roots that reduces sprouting numbers, size, and vigor, similar to sprouting patterns observed with trees (Kays and Canham 1991). A similar timing of cut-stump treatment with and without herbicides response was observed by Petrice and Haack (2011) for white ash trees. This timing of cutting result in the current study loses some importance as it disappears by the second year after treatment.

First year results from the current study are supported by two recent non-refereed studies that tested cut-stump herbicide treatments with glyphosate applied to oriental bittersweet (both studies were found as Master of Science theses). Lynch (2009) conducted a one-year study in West Virginia, U.S., of individual, large ( $1-5 \mathrm{~cm}$ diameter) oriental bittersweet control that included a cut-stump herbicide treatment with $50 \%$ Accord $(26.9 \%$ a.i. glyphosate) applied in July. Vines were climbing trees in a fully-stocked, 55-year-old forest. Sixteen weeks after treatment, the cut-stump herbicide treatment had only $10 \%$ of the vines survive, compared to $60 \%$ survival for cut-only treatments. Across all treatments, many vine sprouts were observed to die over that first growing season. Lynch (2009) also described that cut-stump with herbicide treatment and a cut-only treatment had average sprout numbers of 8 and 20 per treated vine, and average sprout length of $12 \mathrm{~cm}$ and $43 \mathrm{~cm}$, respectively, which are similar to the current study. Wooten (2013) studied population-level control in Pennsylvania, U.S., by treating all vines (small and large) on plots with clonally-isolated, tree-climbing oriental bittersweet. Cut stump with glyphosate (GlyphoMate $41^{\circ} ; 41 \%$ a.i. glyphosate) was applied to treated vines in July. Total number of vines alive at the end of the first growing season with herbicide treatment was found not to be different than cutting alone. Unfortunately, both studies were concluded after the first year; therefore, there are no data on a second year of treatment response. As in the current study, a second year of study may have changed conclusions.

In the current study's second year after treatment, herbicide effects were nearly gone-vine cutting alone produced nearly or the same effects as cutstump treatment with herbicide. Study 1 still had a significant herbicide treatment effect into the second year, but the increase in percent mortality with herbicides was much lower in Year 2 compared to Year 1. In Year 1, herbicide treatments nearly doubled the percent kill (44\% versus $86 \%$ ), but in Year 2 the increase in percent kill was only $8 \%$ (92\% versus $\sim 100 \%)$. In Study 2, percent mortality did not differ among the treatments after the second year, averaging $89 \%$ across the treatments. While the average percent mortality in the cut-only plots was $70 \%$, this was not 
statistically different than the herbicide treatments that averaged $98 \%$. The low percent kill for the cutonly treatment in the second year of Study 2 is due to very low percent kill in only one plot-20\% kill in the youngest, northern most treatment plot (Lake George site). The other two cut-only plots in Study 2 had $90 \%$ and $100 \%$ mortality. It is not clear why the one plot had such low mortality. It may be that the smaller, younger vines in the northern plot, averaging $2.9 \mathrm{~cm}$ diameter and 15 years old, were not as readily killed with cutting alone, as compared to the older and larger vines treated in the southern plots, where the vines averaged 5.2 and $6.9 \mathrm{~cm}$ diameter, and 26 and 36 years old. In addition to vine size considerations to explain high sprout survival in the one plot, it could be that the cut-only plot in the northern site had a more open canopy, allowing for greater survival of stump sprouts due to higher plotlevel light levels (discussion follows). Unfortunately, light quantity was not measured in the current study.

It was fortuitous that a second year of study was added to observe treatment effects, as the conclusions based on the second year are very different than there would have been had the analysis been based on the first year alone. Three other studies of cut-stump treatments conducted for two years affirm the importance of a second year of study. Ballard and Nowak (2006) observed that trees treated with cut-stump herbicides often were alive after the first year, but dead the second year. Petrice and Haack (2011) reported higher mortality for ash tree species treated with cutting only and cut stump with herbicide in the second year compared to the first. Zedaker et al. (1987) observed the opposite: trees that were thought to be dead after one year were alive the second year, which still affirms the importance of two years of study. In the current study, at the end of the first year after treatment, many treated vines were not dead (yet), and had many large basal sprouts. Nearly all of these sprouts were dead by the end of the second year. Of the 326 vines measured in Year 2 post treatment, only 17 were still alive, and eight of these were in one cut-only plot.

It is not clear why nearly all sprouts from the first year died by the end of the second year. One factor could have been herbivory as oriental bittersweet is browsed by deer and other mammals (Ashton and Lerdau 2008; Lynch 2009). Impact of deer and other herbivores on current study sprouts was observed to be low, as many sprouts in the second year were observed to be standing dead without evidence of browse, and all sites had large, live sprouts at the end of the second year (albeit a greatly reduced number compared to the first year). Additionally, high second-year mortality was generally consistent across the three broadly separated study sites across the Hudson Valley, with likely differences in browsing pressure that did not cause high site-level variation in mortality (see non-significant block effect for Study 2).

A more likely reason for the near complete mortality of stump sprouts through two years is that sprouts may have exhausted carbohydrate reserves in the roots after the first year. Carbohydrate storage and release are long recognized as key to the vegetative regrowth of woody plants (Kayes and Canham 1991; Kozlowski et al. 1991; Kozlowski 1992), including vines (Mooney and Gartner 1991). Woody vines have a wide variety of carbohydrate storage patterns, with some species having storage in stems, and others in roots (Mooney and Gartner 1991). Existing information of vines and their carbohydrate compounds and carbon storage capacity comes from agronomic literature. Vitis species (grapes), because of their economic value, have had detailed plant physiology study. The bittersweet family (Celastraceae) has similar anatomical vine structure as the grape family (Vitaceae) (Carlquist 1991), so research on grapes could apply to bittersweet. Winkler and Williams (1945) (cited in Mooney and Gartner 1991) found that bark in older grapevine roots had greater than $50 \%$ total non-structural carbohydrates (this is the source of carbon available to developing sprouts, in addition to defenses) that was nearly depleted by the end of the growing season-stored carbon in roots was enough to only support one year's worth of grape development, which classed them as having a "deep depletion cycle" of total non-structural carbohydrates. It may be that oriental bittersweet has similar carbon dynamics, and can support sprouts for only one year, after which each sprout must produce enough photosynthates to carry out its life needs. Apparently, this may not have been the case in the current study where all of the sprouts were growing in full shade of a forest canopy.

While oriental bittersweet is considered to be shade tolerant as a seedling with a capacity to shift ecophysiology to be more like a shade-intolerant 
in full sun (Greenburg et al. 2001; Ellsworth et al. 2004), it may be less shade tolerant throughout its life than reported. In the current study, higher density of small oriental bittersweet along the forest edge versus interior supports the notion that oriental bittersweet is less than shade tolerant, and may possibly be shade intermediate. It is known that oriental bittersweet reproduces better as seedlings, sprouts, and root suckers in forest gaps, old field and clearcuts, and open forest edges (Fike and Niering 1999; Silveri et al. 2001; Londré and Schnitzer 2006), indicating that when vine-invaded systems and vines themselves are disturbed, regeneration is successful in areas with increased sunlight. A key aspect of the current study may be that the vines were treated without disturbing the forest. It is expected that if both vines and the subject trees and forests were disturbed, long-term treatment effects may have been different; specifically, herbicide use may have been shown to produce added kill and control of oriental bittersweet populations because more of the sprouts would have stayed alive in the cut-only treatment.

\section{CONCLUSIONS AND RECOMMENDATIONS}

Based on two years of field study, researchers conclude that it may not be necessary to apply herbicide via cut-stump methods to kill large oriental bittersweet vines (where large means vines that $>2-3 \mathrm{~cm}$ in diameter) in areas where the invaded trees and forest systems are not significantly disturbed. Cutting alone of vines whose stumps remained in full shade resulted in $>95 \%$ kill across the study plots, excluding the one northern plot in Study 2 with only $20 \%$ kill and vines averaging $2.9 \mathrm{~cm}$ diameter. Herbicide treatments resulted in nearly $100 \%$ kill, but this result was not statistically different from the percent kill with cutting alone.

The recommendation to not use herbicides to kill large, cut-stump treated vines is in contrast with published recommendations. Hutchinson (1992) is often a cited source for using cut-stump herbicides to kill oriental bittersweet vines (e.g., see citation in Williams and Timmins 2003; Webster et al. 2006), with a recommendation to use a 100\% Roundup mix (glyphosate herbicide similar in rate to the highconcentration herbicide treatment in the current study) on cut vine surfaces late in the growing season (just after late frost). But, this and other like recom- mendations in the literature are apparently not based on field research. Discovering published literature full of recommendations to cut-stump treat oriental bittersweet vines with herbicides that is not founded in research and the scientific method highlights the importance of conducting long-term herbicide research in support of vegetation management.

Results from the current study can be implemented immediately and across the range of oriental bittersweet. The recommendation to not use herbicides in conjunction with cut-stump methods to kill oriental bittersweet may apply only to large vines whose cut stumps are in shade after treatment. Large vines are defined as having a minimum, near-ground stem diameter of $2-3 \mathrm{~cm}$. These vines are usually twining around large trees, growing up into the canopy, and causing problems to tree health. While many management guidelines include cut-stump treatment with herbicide to kill tree climbing oriental bittersweet vines, it seems that these guidelines are anecdotal and not based on rigorous research as used in the current study.

Current study results likely do not apply to smaller oriental bittersweet, particularly those small, trailing, shrub-like vines that are commonly abundant in old fields and mowed roadside rightsof-way. These small vines often look like small tree or shrub seedlings, and with populations observed with over 100,000 stems per ha (C. Nowak, personal observation). It may be that persistent mowing or foliar herbicides may be needed to control these younger oriental bittersweet populations.

Various other woody vines native to North America can cause problems for vegetation managers similar to oriental bittersweet, but most prominent is wild grapevines (Vitis spp.). Research on control of wild grapevines in context of forestry was conducted in the eastern United States over the past five decades. Trimble and Tyron (1979) synthesized earlier research and produced management guidelines for cut-stump treatments for grape similar to the current study with oriental bittersweet. In general, Trimble and Tyron (1979) reported that cut grapevines under forest canopies produced sprouts that died in three years, but if the overstory was removed, then the grape sprouts thrived. They recommended severing grape vines growing in wellstocked stands as an effective and inexpensive way to eliminate them, and that this method works 
because grapevines are shade-intolerant. While wild grapes are shade-intolerant throughout their lives, and oriental bittersweet is considered shade tolerant (though argued in the current study as possibly being less shade-tolerant) as a seedling and shadeintolerant as a climbing vine, control recommendations for grape and large bittersweet vines are intriguingly similar. Smith (1984) well captured the recommendation for grapes that has bearing for oriental bittersweet, paraphrased as follows. Vines can be controlled in shaded areas of forest stands by severing or cutting the large vines that grow in trees. Vines can be severed near groundline using blades, hatchets, or chain saws depending on vine size. The cut vine will likely resprout, but those sprouts will die within a few years and not become a problem in the future, barring any drastic increase in sunlight with overstory removal or natural disaster,

Research on use of herbicides to control oriental bittersweet should continue to confirm (or not) and extend the results of the current study. At the least, the current study could be duplicated to determine if the high two-year mortality by cutting vines alone without herbicides can be reproduced. Future cut-stump studies with glyphosate could follow the same designs in the current study, but should add the following independent variables: size of vines that are smaller $(<1.3 \mathrm{~cm})$ and younger than in the current study; cut stumps of treated vines exposed to varying amounts of sunlight after treatment; and measured levels of herbivory (fence off some of the treated stumps to control herbivore access). Clearly, the mechanisms to explain why there was such high mortality in the cut-only plots after two years across treatments needs to be investigated with both observational and manipulative experiments. Results of the current study do not address the problems of oriental bittersweet growing in open fields with shrub-like form. The high density and small stem diameter does not match well with cut-stump methods, but other herbicide application techniques could be tested, including cut stubble and foliar. Like cut-stump treatments of oriental bittersweet, there is a paucity of published research on foliar application of herbicides to control oriental bittersweet.

\section{Management Implications for Utility Foresters and Other Arborists Managing Hazard Trees}

Hazard tree management revolves around evaluating individual tree risk and actively removing high-risk trees. Highly hazardous trees are those with structural problems that may cause near-term failurethe trees could fall over due to excessive crown weight and loading (snow, wind), as well as stem defects (decay, lean, deformity). Vines, including but not exclusive to oriental bittersweet, can cause both these problems. A hazard tree management program should include a vine management program.

When large oriental bittersweet vines (where "large" is defined as those vines growing into tree canopies with a stem diameter of $2 \mathrm{~cm}$ or more) are observed growing in danger trees, they should be killed before they cause damage to the tree and increase hazard. Today, this is a low cost treatment by just cutting vines in danger trees as they are encountered; a management program of this type could save hundreds or thousands of dollars of treatment later on to remove a tree that is too hazardous or recover from the damage of a fallen tree. It is important to emphasize, and based on the current research reported in this paper, that cutting vines alone can work to kill or otherwise control the vine problem, particularly vines growing in forest where the stem is in the shade. Herbicide treatment of large oriental bittersweet vines-and likely other vines, such as grapes, Virginia creeper, and poison ivy-is not necessary in shaded situations, which can save time, money, and associated environmental effects that come with cut-stump treatment.

It is important to reflect on the fact that existing management guidelines for oriental bittersweet include cut-stump treatment with herbicide to kill tree-climbing vines. It seems these guides are in error, and in fact are based on no empirical research. Vegetation managers-utility foresters, arborists, and all practitioners for this mattershould be critical of vegetation management guidelines that are not based on empirical field research. 
Acknowledgments. The authors acknowledge monetary and administrative support from the New York State Department of Transportation, and project management by John Rowen. Additionally, John and the NYSDOT Technical Advisory Committee provided numerous and useful comments on previous drafts of a project report that is the basis for this paper.

The following students from SUNY-ESF are acknowledged herein for their contributions to the successful completion of these studies from their work as Research Aides, Research Analysts, and Research Project Assistants: Collin Bartholomew, Ian Freeburg, Gavin MacKellar, Quincey Oliver, Juliana Quant, William Van Gorp, Danielle Wilder, and Ryan Wynne all contributed to field work and data management. Dr. Eddie Bevilacqua and the SUNYESF Dendrochronology Lab provided space and resources to conduct vine stem analyses. Mr. Dave Hayes, National Park Service, facilitated access and work at the Vanderbilt Mansion National Historic Site. All of these people were instrumental in finishing this research work.

\section{LITERATURE CITED}

Abrahamson, L.P. 1983. Control of beech root and stump sprouts by herbicide injection of parent trees. Forest Research Note RNSOF-81-001. State University of New York College of Environmental Science and Forestry, Syracuse, New York, U.S.

Ahrens, W.H., D.J. Cox, and G. Budhwar. 1990. Using the Arcsine and square root transformations for subjectively determined percent data. Weed Science 38:452-458.

Albers, J.S., J.D. Pokorny, and G.R. Johnson. 2006. How to detect and assess hazardous defects in trees. In: J.D. Pokorny (Coord. Ed.). Urban Tree Risk Management: A Community Guide to Program Design and Implementation. MN, NA-TP-03 St. Paul, MN: UDSA Forest Service.

ANSI (American National Standard Institute, Inc.). 2011. American National Standard for Tree Care Operations-Tree, Shrub, and Other Woody Plant Maintenance-Standard Practices (Tree Risk Assessment a. Tree Structure Assessment). American National Standard Institute, Inc., ANSI A300 (Part 9), Tree Care Industry Association, Manchester, New Hampshire, U.S.

ANSI (American National Standard Institute, Inc.). 2012. American National Standard for Tree Care Operations-Tree, Shrub, and Other Woody Plant Maintenance-Standard Practices (Integrated Vegetation Management a. Electric Utility Rightsof-way). American National Standard Institute, Inc., ANSI A300 (Part 7), Tree Care Industry Association, Manchester, New Hampshire, U.S.

Ashton, I.W., and M.T. Lerdau. 2008. Tolerance to herbivory, and not resistance, may explain differential success of invasive, naturalized, and native North American temperate vines. 14:169-178.

Ballard, B.D., and C.A. Nowak. 2006 Timing of cut-stump herbicide applications for killing hardwood trees on powerline rights-ofway. Arboriculture \& Urban Forestry 32:118-125.

Carlquist, S. 1991. Anatomy of vine and liana stems: A review and synthesis. pp. 53-72. In: F.E. Putz and H.A. Mooney (Eds.). The Biology of Vines. University Press, Cambridge.

Dreyer, G.D. 1994. Element stewardship abstract for Celastrus orbiculatus. The Nature Conservancy, Arlington, Virginia, U.S.

Dreyer, G.D., L.M. Baird, and C. Fickler. 1987. Celastrus scandens and Celastrus orbiculatus: Comparisons of reproductive potential between a native and an introduced vine. Bulletin of the Torrey Botanical Club 114:260-264.
Dukes, J.S., J. Pontius, D. Orwig, J.R. Garnas, V.L. Rodgers, N. Brazee, B. Cooke, K.A. Theoharides, E.R. Stange, R. Harrington, J. Ehrenfeld, J. Gurevitch, M. Lerdau, K. Stinson, R. Wick, and M. Ayres. 2009. Response of insect pests, pathogens, and invasive plant species to climate change in the forests of northeastern North America: What can we predict? Canadian Journal of Forest Research 39:231-248.

Ellsworth, J.W., R.A. Harrington, and J.H. Frownes. 2004. Survival, growth and gas exchange of Celastrus orbiculatus seedlings in sun and shade. American Midland Naturalist 151:233-240.

Fike, J., and W.A. Niering. 1999. Four decades of old field vegetation development and the role of Celastrus orbiculatus in the northeastern United States. Journal of Vegetation Science 10:483-492.

Greenburg, C.H., L.M. Smith, and D.J. Levey. 2001. Fruit fate, seed germination, and growth of an invasive vine-An experimental test of 'sit and wait' strategy. Biological Invasions 3:363-372.

Guggenmoos, S. 2003. Effects of tree mortality on power line security. Journal of Arboriculture 29(4):181-196.

Guggenmoos, S., and T.E. Sullivan. 2007. Outside right-of-way tree risk along electric transmission lines. Accessed 13 February 2015. <www.ecosync.com/tdworld/SideTreeRisk.pdf>

Hou, D. 1955. Revision of the Genus Celastrus. Annals of the Missouri Botanical Garden 42:215-302.

Hutchinson, M. 1992. Vegetation management guideline: Roundleaved bittersweet (Celastrus orbiculatus Thunb.). Natural Areas Journal 12:161.

Kays, J.S., and S.D. Canham. 1991. Effects of time and frequency of cutting on hardwood root reserves and sprout growth. Forest Science 37:524-539.

Kochenderfer, J.D., J.N. Kochenderfer, and G.W. Miller. 2006. Controlling beech root and stump sprouts using the cut-stump treatment. Northern Journal of Applied Forestry 23:155-165.

Kozlowski, T.T. 1992. Carbohydrate sources and sinks in woody plants. Botanical Review 58:107-222.

Kozlowski, T.T., P.J. Kramer, and S.G. Pallardy. 1991. The Physiological Ecology of Woody Plants. Academic Press, San Diego, California, U.S.

Londré, R.A., and S.A. Schnitzer. 2006. The distribution of lianas and their change in abundance in temperate forests over the past 45 years. Ecology 87:2973-2978.

Lutz, H.J. 1943. Injuries to trees caused by Celastrus and Vitis. Bulletin of the Torrey Botanical Club 70:436-439.

Lynch, A.L. 2009. Investigating distribution and treatments for effective mechanical and herbicide application for controlling oriental bittersweet (Celastrus orbiculatus Thunb.) vines in an Appalachian hardwood forest. Master of Science thesis, West Virginia University, Morgantown, West Virginia, U.S.

Manning, T., P. Bradford, C. White, D. Rowe, N. Densmore, and S. Guy. 2002. British Columbia's dangerous tree assessment process. pp. 863-868. In: USDA Forest Service General Technical Report PSW-GTR-181.

Maruthaveeran, S., and A. Yaman 2010. The identification of criteria and indicators to evaluate hazardous street trees of Kuala Lumpur, Malaysia: A Delphi study. Journal of Forestry 108(7):360-364.

McNab, W.H., and M. Meeker. 1987. Oriental bittersweet: A growing threat to hardwood silviculture in the Appalachians. Northern Journal of Applied Forestry 4:174-177. 
McNab, W.H., and P.E. Avers. 1994. Ecological Subregions of the United States: Section Descriptions. United States Department of Agriculture Forest Service, Administrative Publication WOWSA-5.

Merriam, R.W. 2003. The abundance, distribution and edge association of six non-indigenous, harmful plants across North Carolina. Journal of the Torrey Botanical Society 130: 283-291.

Mooney, H.A., and B.L. Gartner. 1991. Reserve economy of vines. pp. 161-179. In: F.E. Putz and H.A. Mooney (Eds.). The Biology of Vines. University Press, Cambridge.

Natural Resources Conservation Service. 2014. Web Soil Survey. Accessed 02 May 2014. <websoilsurvey.sc.egov.usda.gov>

Nowak, C.A. 2010. Importance, identification and assessment of both danger and hazard trees located outside electric transmission line rights-of-way. Technical Report 1019879, Electric Power Research Institute, Palo Alto, California, U.S.

Patterson, D.T. 1974. The ecology of oriental bittersweet, a weedy introduced vine. Doctoral Dissertation, Duke University, Raleigh, North Carolina, U.S.

Peck, C.J. 2014. Controlling oriental bittersweet using glyphosate herbicide treatments in the Hudson Valley. Master of Science Thesis, State University of New York College of Environmental Science and Forestry, Syracuse, New York, U.S.

Petrice, T.R., and R.A. Haack. 2011. Effects of cutting time, stump height, and herbicide application on ash (Fraxinus spp.) stump sprouting and colonization by emerald ash borer (Agrilus planipennis). Northern Journal of Applied Forestry 28:79-83.

Puolos, H.M., and A.E. Camp. 2010. Decision support for mitigating the risk of tree induced transmission line failure in utility rights-of-way. Environmental Management 45:217-226.

Putz, F.E. 1991. Silvicultural effects of liana. pp. 493-501. In: F.E. Putz and H.A. Mooney (Eds.). The Biology of Vines. University Press, Cambridge, UK.

Robertson, D.J., M.J. Robertson, and T. Tague. 1994. Colonization dynamics of four exotic plants in a northern Piedmont area. Bulletin of the Torrey Botanical Club 121:107-118.

SAS Institute Inc. 2011. SAS version 9.3. SAS Institute Inc., Cary, North Carolina, U.S.

Schnitzer, S.A., and F. Bongers. 2002. The ecology of lianas and their role in forests. Trends in Ecology and Evolution 17:223-230.

Siccama, T.G., G. Weir, and K. Wallace. 1976. Ice damage in a mixed hardwood forest in Connecticut in relation to Vitis infestation. Bulletin of the Torrey Botanical Club 103:180-183.

Silveri, A., P.W. Dunwiddie, and H.J. Michaels. 2001. Logging and edaphic factors in the invasion of an Asian woody vine in a mesic North American forest. Biological Invasions 3:379-389.

Simpson, P., and R. Van Bossuyt. 1996. Tree-caused electric outages. Journal of Arboriculture 22(3):117-121.

Smith, H.C. 1984. Forest management guidelines for controlling wild grapevines. United States Department of Agriculture Forest Service, Research Paper NE-548.

Stehman, S.V., and M.P. Meredith. 1995. Practical analysis of factorial experiments in forestry. Canadian Journal of Forest Research 25:446-461.

Steward, A.M., S.E. Clemants, and G. Moore. 2003. The concurrent decline of the native Celastrus scandens and spread of the nonnative Celastrus orbiculatus in the New York City metropolitan area. Journal of the Torrey Botanical Society 30:143-146.
Trimble, G.R., Jr., and E.H. Tyron. 1979. Silvicultural control of wild grapevines. West Virginia Agricultural Experiment Station Bulletin 667, Morgantown, West Virginia, U.S.

UAA (Utility Arborist Association). 2009. Utility Best Management Practices, Tree Risk Assessment and Abatement for Fire Prone States and Provinces in the Western Region of North America. Accessed 13 February 2015. <www.utilityarborist.org/research/ resources/TreeRiskAssessmentBMP_20090629.pdf>

USDA FS (U.S. Department of Agriculture Forest Service, State and Private Forestry). 2006. Urban tree risk management: A community guide to program design and implementation. U.S. Department of Agriculture Forest Service, State and Private Forestry, St. Paul, Minnesota, U.S., NA-TP-03-03. Accessed 13 February 2015. <www.na.fs.fed.us/spfo/pubs/uf/utrmm>

Webster, C.R., M.A. Jenkins, and S. Jose. 2006. Woody invaders and the challenges they pose to forest ecosystems in the Eastern United States. Journal of Forestry 104:366-374.

Williams, P.A., and S.M. Timmins. 2003. Climbing spindle berry (Celastrus orbiculatus Thunb.) biology, ecology, and impacts in New Zealand. Science for Conservation 234, New Zealand Department of Conservation, Wellington, New Zealand.

Winkler, A.J., and W.O. Williams. 1945. Starch and sugars of Vitis vinifera. Plant Physiology 20:412-432.

Wooten, J. 2013. Techniques to suppress invasive oriental bittersweet (Celastrus orbiculatus) on Presque Isle State Park in Erie, Pennsylvania. Master of Science thesis, State University of New York at Fredonia, Fredonia, New York, U.S.

Zedaker, S.M., J.B. Lewis, D.W. Smith, and R.E. Kreh. 1987. Impact of season of harvest and site quality on cut-stump treatment of Piedmont hardwoods. Southern Journal of Applied Forestry 11:46-49.

Christopher A. Nowak (corresponding author)

State University of New York

College of Environmental Science and Forestry

1 Forestry Drive

Syracuse, New York 13210, U.S.

canowak@esf.edu

Caryl J. Peck

Environmental Consultants, Inc. Red Bank, New Jersey 07701, U.S. 
Résumé. Le bourreau des arbres (Celastrus orbiculatus) est une vigne exotique ligneuse et envahissante introduite en Amérique du Nord du milieu à la fin des années 1800 en provenance d'Asie orientale. Cette vigne est problématique, car elle peut tuer des arbres par compétition ou par contrainte mécanique, ce qui en retour crée des problèmes pour les arboriculteurs qui travaillent au dégagement des servitudes de services publics et dans d'autres interventions sur des arbres à risques. Le bourreau des arbres est de plus en plus répandu dans tout l'est des États-Unis. Deux expériences de traitement sur le terrain ont été menées dans la vallée de l'Hudson, dans l'État de New York pour évaluer différentes moments pour la coupe et les effets d'herbicides à base de glyphosate sur la mortalité de grosses vignes. Bien que les résultats de la première année aient démontré que l'utilisation d'herbicides en combinaison avec la coupe des vignes était nécessaire afin d'atteindre des taux élevés de mortalité, ce ne fut pas le cas avec les résultats de la deuxième année. La coupe des vignes sans recours aux herbicides produit le même taux élevé de mortalité du bourreau des arbres après la deuxième année ( $>90$ $\%$ de mortalité) que les coupes avec utilisation d'herbicide sur les souches. Il peut être important que le taux élevé de mortalité des vignes soit en lien avec la grosseur des plants de vigne et le fait que les souches aient été situées en sous-bois ombragé. Les chercheurs ont conclu qu'il n'est peut-être pas nécessaire d'appliquer de l'herbicide sur les souches suite à la coupe afin de tuer les plants de bourreau des arbres ayant un diamètre minimal plus grand que 2 à $3 \mathrm{~cm}$ et qui poussent dans les zones ombragées en sous-bois. Il semble qu'en ce qui a trait aux bourreaux des arbres de toute dimension qui se développent en plein soleil, il est souhaitable de recourir à un traitement avec herbicide afin d'atteindre des niveaux acceptables de mortalité et de contrôle.

Zusammenfassung. Der Rundblättrige Baumwürger (Celastrus orbiculatus) ist ein invasiver, exotischer, holziger Wein, der nach Nordamerika in der Mitte bis Ende des 18.Jahrhunderts aus Ostasien eingeführt wurde. Dieser Wein ist problematisch, weil er Bäume durch Konkurrenz und mechanischen Stress töten kann, was im Gegensatz Probleme für die verantwortlichen Arboristen im Bereich von Oberlandleitungen und anderen Baumarbeiten schaffen kann. Der Rundblättrige Baumwürger wird im Osten der Vereinigten Staaten ein großes Problem. Zwei manipulative Feldexperimente wurden im Hudson Tal im Bundesstaat New York durchgeführt, um die beste Zeit zum Schneiden zu finden und die Glyphosat-Herbizid-Wirkung auf die Mortalität großer Weine zu testen. Während die Ergebnisse aus dem ersten Jahr zeigten, dass Herbizide in Verbindung mit Schnittmaßnahmen erforderlich waren, um hohe Absterberaten zu erzielen, konnte das für das zweite Jahr nicht bestätigt werden. Der Rückschnitt von Wein ohne Herbizide produzierte nach dem zweiten Jahr die gleiche hohe Mortalität von Rundblättrigem Baumwürger wie die Schnittbehandlung mit Herbizideinsatz. Es könnte wichtig sein, dass eine hohe Sterberate von geschnittenem Wein mit der Weingröße verbunden ist und das die Stumpen im Schatten lagen. Die Forscher schlossen daraus, dass es zum Abtöten nicht nötig sei, ein Herbizid auf die abgeschnittenen Stumpen des Baumwürger-Weins zu applizieren, die ein Minimum an Stammdurchmesser von $>2-3 \mathrm{~cm}$ haben und dort wachsen wo schattige Bedingungen herrschen. Es scheint, dass jede Größe vom Rundblättrigen Baumwürger, der in der Sonne wächst, ein Herbizid benötigt, um akzeptable Absterberaten zu erzielen.

Resumen. Celastrus orbiculatus es una enredadera leñosa exótica invasiva introducida en América del Norte a mediados y finales de 1800s desde el Este de Asia. Esta enredadera es problemática ya que puede matar a los árboles a través de la competencia y el estrés mecánico, que a su vez crea problemas a los profesionales del cuidado de árbol en el derecho de vía y otros peligros en el trabajo en el árbol. La enredadera oriental es cada vez más frecuente en todo el este de Estados Unidos. Se llevaron a cabo dos experimentos de campo a través del Valle de Hudson en el estado de Nueva York para investigar los efectos del período de corta y el herbicida glifosato sobre la mortalidad de la enredadera. Si bien los resultados del primer año indicaron la necesidad de herbicidas con el corte para lograr altas tasas de mortalidad, esto no fue así con los resultados del segundo año. La corta de la enredadera sin herbicidas producen la misma alta tasa de mortalidad de la enredadera oriental después del segundo año (> 90\% de mortalidad) como tratamientos de corte de tocón con herbicidas. Puede ser importante que la alta mortalidad de la enredadera cortada esté relacionada con el gran tamaño de la misma y los tocones en la sombra del bosque. Los investigadores llegaron a la conclusión de que puede que no sea necesaria la aplicación de herbicidas mediante métodos de corte de tocón para matar enredaderas orientales que tienen un diámetro mínimo parental $>2-3 \mathrm{~cm}$ y estén creciendo en áreas donde los tocones están en la sombra. Parece que cualquier tamaño de la enredadera que esté creciendo en plena luz del sol puede requerir tratamiento con herbicidas para producir niveles aceptables de mortalidad y control. 